\title{
Flake Dosage Form
}

National Cancer Institute

\section{Source}

National Cancer Institute. Flake Dosage Form. NCI Thesaurus. Code C68982.

A solid composed of active and/or inert ing redient(s) that resembles small, thin chips. 